As contribuições especiais na Constituição de 1988

Rômulo Maya 157

Conceito e fundamentos de família e sua evolução na ordem jurídica

Carlos Silveira Noronh 161

Efetividade e processo cautelar - Carlos Alberto Alvaro de Oliveira

175

A função do defensor dos interesses do

Estado no processo administrativo-tributário

Gentil André Olsson 180

A aposentadoria especial dos professore

Valdacyr S. Scomazzon 190

Procedimentos ordinário e sumaríssimo

Ovídio A. Baptista da Silva 205

Os elementos da ação

José Maria Rosa Tesbeiner

A conferência mundial de

Direitos Humanos:

Lições de Viena

Antônio Augusto Cançado Trindade 232

O Código Civil Alemão - Adolescente ou ancião?

Michael R. Will 238

A interpretação econômica da lei tributária e o fato gerador do Imposto Provisório sobre Movimentação Financeira

Carlos Klein Zanini 248

Restrições à concessão de liminares

Teori Albino Zavascki 256

\section{PARECER}

Servidão predial não-aparente, transcrição no Registro de Imóveis

Henrique Fagundes Filho

\title{
A Convenção de Viena (1980) e a resolução do contrato por incumprimento
}

Trabalho apresentado no Congresso "Contratos Internacionais e MERCOSUL", setembro 1992, na Faculdade de Direito/UFRGS

Ruy Rosado de Aguiar Júnior

Prof. Direito Civil e Mestre em Direito - Faculdade de Direito da UFRGS

Ministro do Superior Tribunal de Justiça

SUMÁRIO

Introdução; 1ํ. Parte - Características e pressupostos da resoluçāo; 1. Âmbito de incidência; 2. Resoluçāo extrajudicializada; 3. Resolucão ipso facto; 4. Subsidiariedade, jus variandi, cumulatividade; 5. Culpa do devedor: 2" Parte - Procedimentos e efeitos da resoluçã 1 . Opcões do credor; 2. Declaração de resolução; 3. Perdas

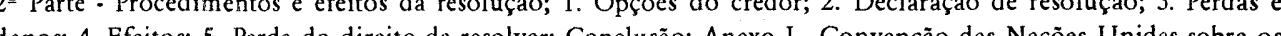
contratos de compra e venda internacional de mercadorias; Anexo II - Legislação brasileira citada.

\section{Introdução}

A Convenção de Viena (1980) é um passo à frente das duas Convenções firmadas na Conferência de Haia (1964), lei uniforme sobre a venda internacional de bens (ULISLUVI) e lei uniforme sobre a formação dos contratos de venda internacional de bens (ULFC-LUFC), estando destinada a exercer. grande influência nas relações comerciais internacionais, pois conta com a subscrição ou a adesão dos principais países do mundo desenvolvido. Está em vigor desde 1988, sendo adotada, na América do Sul, pela Argentina, Chile e Venezuela.

$\mathrm{O}$ Brasil não assinou nem aderiu à Convenção, mas seu estudo tem duplo interesse para nós.

A Convenção aplica-se aos contratos de compra e venda de mercadorias celebrados entre partes que tenham o seu estabelecimento em Estados contratantes da Convenção (art. 1, 1,a), e essa hipótese não nos atinge, mas também regula aqueles contratos aos quais se aplicar, pelas regras do direito internacional, a lei de um Estado contratante (art. 1, 1, b). Ora, a Lei de Introdução ao Código Civil Brasileiro reza: "Art. 9. Para qualificar e reger as obrigações, aplicar-se-á á lei do país em que se constituírem... $\S 2^{\circ}$. A obrigação resultante do contrato reputa-se constituída no lugar em que residir o proponente". Por aí se vê que o contrato de compra e venda celebrado entre parte estabelecida no Brasil e outra na Argentina ou no Chile, por exemplo, provindo desta a proposta de negócio, ou nestes países se constituindo a obrigação, a nossa regra de direito internacional privado faz incidir sobre tal contrato a lei deste outro país contratante da Convenção, a qual será por isso aplicável, na forma do seu art. $1,1, b^{1}$

Mas também é da nossa conveniência o estudo da Convenção porque ela, reproduzindo estruturalmente o regime jurídico viente no Brasil, introduz princípios e critérios modernos - como o da boa-fé objetiva - para a regulação e a interpretação dos contratos de compra e venda, que bem nos podem servir de parâmetro e orientação doutrinária ou legislativa.

\section{Parte}

Características e pressupostos da resolução

\section{1. Âmbito}

A resolução é modo de extinção das relações obrigatórias pelo fato superveniente do incumprimento do devedor, que a maio- 
ria das legislações nacionais reserva aos contratos bilaterais (Brasil), ou, quando mais, também para os unilaterais onerosos, como o mútuo (Argentina). Regulando a Convenção de Viena os contratos de compra e venda internacional de mercadorias, que são bilaterais, todos os contratos dentro do seu âmbito de incidência admitem a resolução, seja por iniciativa do comprador, seja pela do vendedor.

Contendo previsão normativa genérica, aplicável a todos os contratos, a Convenção dispensa o requisito de cláusula contratual específica inserida pelas partes na celebração do contrato, dispondo sobre a resolução. Os seus enunciados funcionam, assim, como os preceitos legislativos nacionais que estatuem sobre a resolução legal. Isto é, pela Convenção, a resolução prescinde de manifestação expressa da vontade das partes, no momento da celebração da avença ou de cláusula adjeta. Da mesma forma no Brasil, cujo art. 1.092, parágrafo único, do Código Civil, se aplica independentemente de previsão. Há uma diferença, porém. Enquanto a Convenção constitui conjunto de regras de caráter dispositivo, derrogável livremente pelas partes (art. $6^{\circ}$ ), no ordenamento jurídico brasileiro entende-se, com predominância, ser vedado aos contratantes a pré-exclusão do direito de resolver ${ }^{2}$, assim como a pré-definição da gravidade do incumprimento de alguma das partes, quando causar ofensa ao princípio da equivalência.

\section{Resolução Extrajudicial}

Pela Convenção, a resolução se dá extrajudicialmente, mediante declaração do credor ao devedor (arts. 26, 49 e 64). Com isso se afeiçoa ao regime do BGB ( $(326)$, ao do Código Civil Italiano (art. 1.454), ao do Código Civil da Argentina (art. 1.204, II, com a nova redação) e ao do direito angloamericano $^{3}$, nos quais a extinção do contrato se dá pela manifestação de vontade da parte.

Nesse intento de afastar os contratantes dos tribunais, a Convenção ainda vai mais longe: proíbe a interferência do juiz ou do árbitro na concessão de prazo suplementar ao vendedor inadimplente, depois de exer- cido pelo comprador o seu direito resolutivo (art. 43, 3). Essa mesma preocupação de manter o litígio longe dos tribunais se manifesta também no capítulo sobre as perdas e danos (arts. 74 e seguintes), onde são estabelecidos critérios objetivos e pormenorizados para o cálculo da indenização (art. 76) e autorizados comprador e vendedor a efetuarem compras substitutivas ou vendas compensatórias (art. 75).

Este regramento agiliza a resolução e acelera a superação do impasse decorrente do incumprimento, com economia de tempo e dinheiro, além de evitar a dependência a regimes judiciários díspares. Tem o inconveniente, porém, de submeter o devedor à avaliação decisória do credor, na qual interferirá necessariamente elevado componente de subjetivismo, por maior que seja a minudência normativa. Entre os dois valores em jogo, a Convenção inclinou-se decididamente pela fluidez nos negócios internacionais, ainda que eventualmente ocorra perda de justiça em casos concretos.

No Brasil, a resolução legal, prevista nos arts. 1.092, parágrafo único, do Código $\mathrm{Ci}$ vil, 202 e 204 do Código Comercial, depende de procedimento judicializado. É lícito às partes, porém, estabelecer cláusula resolutiva por incumprimento (resolução convencional) e nela dispor sobre o procedimento extrajudicial ${ }^{4}$. Artigos esparsos do Código Civil (art. 1.163 do Código Civil) e do Código Comercial (art. 212) admitem, para situações específicas, a resolução independentemente de juízo.

\section{Resolução ipso facto}

Ao limitar a resolução à declaração da parte, a Convenção não só excluiu a intervenção judicial como requisito para a extinção do contrato, como também eliminou possibilidade anteriormente admitida pela ULIS (Conferência de Haia de 1964), que contemplava a hipótese de resolução ipso facto $^{5}$. O sistema atual é melhor, pois deflui do bom senso que o credor notifique o devedor de seu propósito contrário à continuidade do negócio, definindo a situação; além disto, mantém com o credor a decisão sobre a resolução, que não deve resultar apenas e automaticamente do incumprimento - como se ao devedor fosse dado, descumprindo, extinguir a resolução - mas sim da vontade expressa do credor.

No Brasil, não há resolução legal automática. Somente o pacto comissório (art. 1.163 do Código Civil), quando expressamente contratado (e de forma tão clara que não possa ser confundido com simples cláusula de estilo, a reforçar a regra do art. 1.092, parágrafo único, do Código Civil), permite a extinção sem a comunicação à outra parte, conseqüente apenas do silêncio do vendedor no prazo de dez dias após o vencimento.

\section{Subsidiariedade, jus variandi,} cumulatividade

A Convenção, assim como a lei brasileira, não tem a resolução como opção subsidiária do credor, como se pudesse ser utilizada somente à falta de alternativa que garantisse o cumprimento do contrato. $O$ art. 45, I, a, autoriza o comprador a exercer alternativamente os direitos previstos nos arts. 46 a 52 (execução, indenização ou resolução), o mesmo concedendo ao vendedor (art. 61).

Não há regra sobre o jus variandi, que a princípio deve ser admitido como inerente ao sistema, podendo o credor variar de pedido, enquanto isso não for incompatível com as circunstâncias e ofensivo ao princípio da boa-fé (art. $\left.7^{0}, 1\right)$. Proibida expressamente está apenas a ação do credor enquanto fluir o prazo suplementar por ele concedido para a execução (art. 47, 2, art. $62,2)$. Há de se considerar ainda incompatível a variação que consistir na exigência da execução depois de notificada a contraparte da declaração resolutória. O mesmo não se diga da possível alteração da mudança do pedido de execução - feito na tentativa de manutenção do contrato e conservação do negócio - para o de resolução, quando evidenciada a impossibilidade ou a dificuldade daquela.
No nosso sistema, a variação é permitida: (a) proposta a ação de cumprimento e depois verificada a impossibilidade do adimplemento, o autor pode pedir a resolução, ainda no curso da ação, uma vez que o artigo 462 do Código de Processo Civil contém a seguinte regra: "Se, depois da propositura da ação, algum fato constitutivo, modificativo ou extintivo do direito influir no julgamento da lide, caberá ao juiz tomá-lo em consideração, de ofício ou a requerimento da parte, no momento de proferir a sentença". Obtida sentença condenatória na ação de cumprimento e inviabilizada sua execução, é permitido ao credor pleitear a resolução; (b) o exercício do direito de resolução convencional, pela via extrajudicial, extingue o negócio, não cabendo mais a execução; (c) proposta a ação de resolução, é lícito ao credor pleitear a execução do contrato (desde que não tenha havido sentença resolutiva com trânsito em julgado) devendo para isso desistir da ação de resolução e propor a de adimplemento (art. 294 do Código de Processo Civil: "Quando o autor houver omitido, na petição inicial, pedido que the era lícito fazer, só por ação distinta poderá formulá-lo".), salvo se já cumulara os dois pedidos sucessivos, requerendo desde logo a resolução ou, não sendo caso, a execução.

A permissão para a cumulação da pretensão indenizatóríia com a resolutória consta dos arts. 45, 2, e 61, 2. Assim também no direito brasileiro, como está no art. 1.092, parágrafo único, do Código Civil.

\section{Culpa do Devedor}

Quando o fato do descumprimento não for imputável ao devedor, mesmo aí cabe a resolução, apenas que sem indenização (art. $79,5)$. No Brasil, a mora do devedor tem como seu elemento a culpa (art. 963 do Código Civil) e quando ela servir de causa à resolução ensejará a condenação do inadimplente ao pagamento de perdas e danos derivados da sua falta. Mas o incumprimento inimputável também oportuniza a resolução, apenas que sem a indenização (art. 866 do Código Civil). 


\section{Incumprimento do devedor}

A resolução do contrato de compra e venda de mercadorias pode ser declarada pelo credor (comprador: art. 49; vendedor: art. 64) desde que haja incumprimento definitivo do devedor, imputável (com direito a perdas e danos) ou inimputável (sem indenização), nos dois casos seguintes: (a) se o incumprimento de qualquer obrigação constituir violação fundamental do contrato (fundamental breacb); (b) se, no prazo suplementar concedido pelo credor, o devedor persistir no incumprimento de sua obrigação principal (para o vendedor: entregar a mercadoria; para o comprador: pagar o preço e aceitar a mercadoria; artigos 49 , $b$, e $64, b$ ).

Dessas disposições decorrem algumas conseqüências bastante relevantes.

A Convenção não distingue entre cláusula fundamental ou acessória, entre condition ou warranty, entre dever ou obrigação principal e dever ou obrigação acessória ou secundária, decorrentes do contrato, da Convenção ou do princípio da boa-fé. Dispensa tratamento unitário a todas as claúsulas e obrigaçōes ${ }^{6}$. Para o fim resolutório, interessará estabelecer se o incumprimento caracteriza uma violação fundamental, assim definida no art. 25: "Uma violação do contrato cometida por uma das partes é fundamental quando causa à outra parte um prejuízo tal que a prive substancialmente daquilo que lhe era legítimo esperar do contrato, salvo se a parte faltosa não previu esse resultado e se uma pessoa razoável, com idêntica qualificação e colocada na mesma situação, não tivesse igualmente previsto".

Equipara à violação fundamental (e mesmo se pode dizer que o pré-define como tal) o incumprimento das obrigações principais do vendedor e do comprador, enumeradas nas alíneas $b$ dos arts. 49 e 64 .

O disposto nas alíneas $b$ dos arts. $49 \mathrm{e}$ 64 conduz seguramente à idéia de que a inexecução da obrigação principal não é causa suficiente, só por si, para extinção do contrato: da inexecução da obrigação de entregar, de aceitar ou de pagar a mercado- ria, não resulta necessariamente uma violaormanece, se falta não ocasionar "um prejuízo tal que a parte fique privada substancialmente daquilo que lhe era legítimo esperar", ou, como diz Larenz, quando a prestação tardia já for economicamente diversa daquela esperada $^{8}$. Assim, por exemplo, nos contratos com data fixa, depois da qual desaparece o interesse do credor, a mora já é quebra substancial; nos outros, nos quais a data serve apenas para fixar a época da exigibilidade da obrigação ou auxilia na orientação programática das partes, o simples incumprimento e insuficiente para resolver. As circunstâncias do contrato, a natureza da prestação e o interesse da parte revelarão, a cada caso, a substancialidade do incumprimento.

Nas suas linhas gerais, assim também ocorre no Brasil. Os arts. 955, 956, parágrafo único, e 1.056 do Código Civil, que definem a mora, o incumprimento que torna inútil a prestação e o efeito da inexecução, constroem um regime jurídico onde a resolução surge como a conseqüência do inadimplemento qualificado pela inutilidade da prestação, só decretável quando desaparecido o interesse do credor em recebê-la.

Também nós não distinguimos entre as diversas espécies de obrigações ou deveres, pois há o inadimplemento sempre que 0 devedor deixar de cumprir a obrigação "pelo modo e no tempo devidos" (art. 1.056 do Código Civil). E toda a desatenção ao que for devido, pela lei, pelo contrato ou pelo princípio da boa-fé, significa incumprimento ou cumprimento imperfeito, que consistirá em violação fundamental ao contrato quando tornar inútil a prestação para o credor ${ }^{9}$

\section{$2^{\mathrm{a}}$ Parte}

Procedimentos e efeitos da resolução

\section{1 - Op̧ôes do Credor}

$O$ incumprimento do vendedor pode ser por demora na entrega ou por cumprimento imperfeito, com vício na quantidade ou qualidade da mercadoria. Havendo demora, o comprador tem à sua escolha: (a) esperar pelo recebimento da mercadoria tardiamente enviada e pedir a indenização pelo dano ${ }^{10}$; (b) conceder prazo ao vendedor para a entrega das mercadorias e resolver após isso, se permanecer a inércia do vendedor; (c) resolver imediatamente, se a violação for fundamental. Havendo cumprimento imperfeito, o comprador pode: (a) aceitar a mercadoria defeituosa em quantidade ou qualidade e pedir indenização; (b) exigir a entrega de mercadorias em substituição, se a falta constituir violação fundamental (art. 46, 2); (c) exigir a reparação da falta de qualidade (art. 43,3$)^{11}$; (d) resolve a obrigação ${ }^{12}$.

No incumprimento do comprador, o vendedor pode: (a) promover a execução forçada da obrigação ${ }^{13}$ se a legislação do país a admitir (art. 28), como é o caso do Brasil; (b) conceder prazo suplementar par o pagamento (art. 63); (c) fazer a especificação que cabia ao comprador omisso (art. 65, 1) (d) vender as mercadorias a cuja conservação esteja obrigado (art. 38); (e) resolver obrigação, se houve violação fundamental

No Brasil, o incumprimento do vendedor que deixa de entregar a coisa vendida autoriza o comprador a "demandar o seu cumprimento com os danos da mora, salvo os casos fortuitos ou de força maior" (art. 202 do Código Comercial). Se a coisa estiver deteriorada, "não sendo o devedor culpado, poderá o credor resolver a obrigação, ou aceitar a coisa, abatido ao seu preço o valor que perdeu" (art. 866 do Código Civil); "sendo culpado o devedor, poderá o credor exigir o equivalente, ou aceitar a coisa no estado em que se acha, com direito a reclamar, em um ou outro caso, indenização das perdas e danos" (art. 867 do Código Civil). Isto é, o credor (comprador) tem ação para executar o contrato e obter mercadoria prometida, ou para recebê-la com abatimento do preço correspondente à deterioração, ou para exigir o seu equivalente, ou aceitá-la no estado em que se encontra, com direito a perdas e danos se houve culpa.
$O$ vendedor que não recebe o pagamento do preço pode promover a ação de adimplemento através de processo de execução - se dispuser de título executivo (arts. 583, 584 e 585 do Código de Processo Civil) - ou de processo de conhecimento (ação de cobrança); se o comprador não lhe recebe a mercadoria, o vendedor pode demandar o comprador pelo preço com os juros legais de mora, requerendo o depósito judicial das mercadorias vendidas por conta e risco de quem pertencer (art. 204 do Código Comercial).

Em qualquer das situações acima, o credor não-inadimplente pode resolver o negócio, uma vez caracterizado o incumprimento qualificado, cumulando o pedido com perdas e danos se houver culpa do devedor.

\section{Declaração de resolução}

Escolhendo de imediato a via resolutiva, presente a violação fundamental, a parte deve efetuar a sua declaração à outra, "através de um meio adequado às circunstâncias" (art. 27), ocorrendo a dissolução com o despacho: The contract is avoided at the moment of dispatch. ${ }^{14}$ Efetuada a notificação nos termos da Convenção e adequadamente, o risco de não chegar ao destino é do destinatário (art. 27) ${ }^{15}$.

No Brasil, ao contrário, a manifestação de vontade do credor que pretende exercer seu direito de resolução convencional, dependente de notificação, só é eficaz depois de recebida pela contraparte.

\section{Perdas e danos}

Escolhendo a resolução, o credor não perde o direito às perdas e danos (art. 45,2), só inexistente quando o incumprimento decorre de fato alheio à vontade do devedor (art. 79, 1 e 5).

A indenização corresponde à satisfação do interesse positivo. "A redação deixa claro que o propósito do art. 74 é, tanto quanto possível, colocar a parte lesada na mesma situação econômica que ela teria se o contrato tivesse sido cumprido"16. Compreende o dano emergente e o lucro cessante. 
No Brasil, ao contrário da maioria dos demais países, onde se admite a consideração apenas do interesse negativo, já se entendia que a indenização cabível no caso de resolução por incumprimento deveria satisfazer 0 interesse positivo do credor $^{17}$. Não temos, é verdade, as regras objetivas e minuciosas dos arts. 74,75 e 76 da Convenção, definindo critérios para avaliação do dano, nem a enunciação do princípio da mitigation, assim como está o art. 77, mas tanto tem sido recomendado em sede doutrinária.

\section{Efeitos}

Resolvida a relação, dois são seus efeitos: liberatório e recuperatório. As partes ficam ambas liberadas de suas obrigações, com o dever de restituírem de imediato ou simultaneamente tudo o que lhe fora fornecido ou pago (art. 81, 1 e 2).

Sempre se admitiu que a resolução tem efeito retroativo, recolocadas as partes no statu quo ante, sendo isso conseqüência natural da sentença que decretar a resolução, portadora desse efeito executivo. Pela Convenção de Viena, adotado o procedimento extrajudicial, cabe à parte credora exigir diretamente da outra a restituição do que já lhe entregara (no tempo avençado ou antecipadamente), oferecendo de sua vez a devolução do que recebera. Junto com a prestação, devem ser entregues todos os proveitos auferidos pela posse do bem, cabendo ao vendedor restituir o preço com juros e, ao comprador, os benefícios retirados da mercadoria (art. 84, 2, a e $b$ ). Assim também no Brasil.

A impossibilidade da restituição é causa de perda do direito formativo de resolução, pois o comprador não pode declarar a resolução se impossibilitado de restituir as mercadorias em estado assemelhado àquele em que as recebera (art. 82). Esta regra no Brasil somente se aplica à resolução convencional, quando o contratante expressamente incluiu tal cláusula no contrato e deveria estar preparado para invocá-la, preservando-se de dispor do bem recebido por força do contrato; na resolução legal, onde se cuida ape- nas de um direito superveniente que surge ao credor por força da incidência da lei, em consequiência de fato posterior à celebração do contrato e eventualmente fora de sua previsão, não se impõe ao credor que pede a resolução o dever de restituir a prestação, em espécie, admitindo-se que o faça pelo equivalente. Fica sempre ressalvada, porém, a incidência do princípio da boa-fé, pois não seria adequado permitir-se a resolução ao credor que dispôs da prestação parcial já recebida, depois de saber do incumprimento definitivo do devedor. Se optou pela execução, somente lhe é lícito promover a ação de adimplemento.

A Convenção impõe ao credor a condição de poder restituir, sob pena de perda do direito de resolver, mas não deixa de temperar o princípio, admitindo exceções se a impossibilidade deriva de fato inimputável (art. 83,2,a), do exame da verificação da conformidade da mercadoria (art. 83, 2 , b) ou da boa-fé (art. 83, 2,c).

A regra geral da resolução com efeito retroativo e recuperatório sofre exceção quando se tratar de contratos com prestações sucessivas. Se a inexecução é apenas de determinada prestação, a resolução pode ser declarada apenas relativamente a esta prestação, permanecendo íntegras as prestações anteriores (art. 73, 1). Para esta, e só para ela, caberá a restituição do que já foi cumprido. Se o incumprimento de uma prestação originar séria dúvida sobre o cumprimento das futuras prestações, o credor pode resolver o contrato para o futuro (art. 73 , 2), restituídas as prestações já efetuadas. $\mathrm{O}$ caso é, mais propriamente, de resilição do contrato duradouro, de execução períodica, forma de extinção por incumprimento que produz efeito ex nunc. O efeito retroativo somente ocorrerá se houver interdependência entre as prestações (art. 73, 3). No Brasil, a legislação específica sobre contratos duradouros (locação urbana, arrendamento rural), também preserva as prestações já executadas.

5. Perda do direito de resolver

A perda do direito de resolver existe para o comprador: (1) se impossibilitado de res- tituir as mercadorias em estado sensivelmente idêntico àquele em que as recebeu (art. 82, 1); (2) se não o exercer em prazo razoável contado: (a) no caso de demora do vendedor, a partir de quando soube da entrega tardia; (b) por outra violação, a partir de quando dela tiver conhecimento ou apó o decurso do prazo suplementar ou da declaração do vendedor de que não o aproveitará para executar suas obrigações, nos casos dos arts. 47, 1, e 48, 2. Em se tratando de mercadoria defeituosa, o prazo razoável é de dois anos, contado da efetiva remess (art. 32, 2), salvo se incompatível com garantia contratual.

A perda do direito de resolver, por im possibilidade de restituição, não significa para o comprador a perda dos demais dire tos concedidos pela Convenção (art. 83)

$\mathrm{O}$ vendedor perde o direito de resolver: (1) em caso de execução tardia, se não o exerceu antes de ter sabido que a execução teve lugar; (2) em caso de outra espécie de violação, se não o exercer em prazo razoáve contado a partir de quando teve ou deveria ter conhecimento da violação, ou a partir do decurso do prazo por ele concedido ao comprador, na forma do art. 63,1 , ou depois de o comprador ter declarado que não o aproveitaria para executar suas obrigações (art. 64, 2).

No direito brasileiro, não há determinação de prazo a partir do qual o credor perde o direito de resolver o contrato. Conside rando que o direito subjetivo de resolução é da espécie dos direitos formativos, e portanto destituído de pretensão, o efeito do tempo sobre ele não pode ser a prescrição (que encobre a pretensão de direito material), mas apenas a extinção do próprio di reito formativo (ou potestativo), isto é, decadência ou preclusão do direito. Par isso, seria indispensável que a legislação nacional contivesse alguma disposição expressa fixando prazo decadencial ou preclusivo o que não ocorre. Apesar de inexistir prazo na lei, admite-se que o direito formativo se extingue quando ocorre a prescrição do direito de crédito a que está ligado, porquanto a extinção do direito de crédito elimina o interesse em resolver a relação de onde ele se originou. Nesse caso, o tempo máximo para o exercício do direito de resolução é o que corresponde ao prazo prescricional para as obrigações pessoais, em vinte anos (art. 177 do Código Civil) ${ }^{18}$

De qualquer forma, no vazio legislativo sobre a fixação de tempo máximo para declaração da vontade de resolver, entende-se que o credor não pode agir depois que criou na contraparte a idéia de não-exercí cio desse direito, aplicando-se para isso o instituto da suppressio, derivado do princípio da boa-fé: o credor perde o direito de resolver se não o exerceu em prazo razoável, permitindo ao devedor a convicção de que optara pela conservação do contrato.

Sobre esse tema convém observar que a Convenção de Viena não fixa prazo, apenas limita em dois anos o tempo máximo para o comprador denunciar a violação do contrato pelo vendedor (art. 39, 2). Uma vez dada essa notícia, o prazo para a declaração de resolução do contrato não é fixado, estatuindo o art. 49, 2 (para o comprador) e art. $64,2, b$ (para o vendedor) um "prazo razoável".

O documento internacional que fixa prazo prescricional é a Convenção de New York, de 1974, que estipula o prazo prescricional de quatro anos a contar da data da remessa efetiva das mercadorias ${ }^{19}$.

\section{Conclusão}

$\mathrm{O}$ regime jurídico instituído pela Convenção de Viena para a resolução do contrato por incumprimento do devedor se caracteriza: - pelo unitarismo com que trata as diversas espécies de obrigações e deveres; pela exigência de violação fundamental do contrato como pressuposto da resolução; pela fixação de prazo suplementar ao devedor; - pelo procedimento extrajudicializado; pela possibilidade de resolução com ou sem fato imputável ao devedor; - pela garantia de cumulação da resolução com a indenização pelos danos; - pela consideração do interesse positivo do credor, como se o contrato tivesse sido efetivamente cumprido; - 
pela adoção do princípio geral da boa-fé objetiva, que há de se entender servir não apenas para a interpretação do contrato mas também determinante do comportamento das partes ${ }^{20}$

No Brasil, estas mesmas são as características gerais do instituto, que é, no entanto, predominantemente judicializado; não prevê prazos suplementares ao devedor; não tem regras delimitadoras de prazo para 0 exercício da ação e não fornece parâmetro para o cálculo da indenização por perdas danos.

\section{Anexo I}

Convenção das Naçōes Unidas sobre os contratos de compra e venda internacional de mercadorias

(Viena - 1980)

\section{Artigos citados}

Artigo 1 - 1. A presente Convenção aplica-se aos contratos de compra e venda de mercadorias celebrados entre partes que tenham o seu estabelecimento em Estados di ferentes: (a) quando estes Estados sejam Estados contratantes; ou (b) quando as regras de direito internacional privado conduzam à aplicação da lei de um Estado contratante. 2. Não é tomado em conta o fato de as partes terem o seu estabelecimento em Estados diferentes quando este fato não ressalte nem do contrato, nem de transações anteriores entre as partes, nem de informações dadas por elas em qualquer momento anterior à conclusão do contrato, ou na altura da conclusão deste. 3 . Não são tomados em consideração para a aplicação da presente Convenção nem a nacionalidade das partes nem o caráter civil ou comercial das partes ou do contrato.

Artigo 2 - A presente Convenção não regula as vendas: (a) mercadorias compradas para uso pessoal, familiar ou doméstico,a menos que o vendedor, em qualquer momento anterior à conclusão do contrato ou na altura da conclusão deste, não soubesse nem devesse saber que as mercadorias eram compradas para tal uso; (b) em leilão; (c) em processo executivo; (d) de valores mobiliários, títulos de crédito e moeda; (e) de navios, barcos, hovercraft e aeronaves; (f) de eletricidade.

Artigo 6 - As partes podem excluir a aplicação da presente Convenção ou, sem prejuízo do disposto no artigo 12 , derroga qualquer das suas disposições ou modificar-lhe os efeitos.

Artigo 7 - 1. Na interpretação da presente Convenção, ter-se-á em conta o seu carácte internacional, bem como a necessidade de promover a uniformidade da sua aplicação e de assegurar o respeito da boa-fé no comércio internacional. 2. As questões respeitantes às matérias reguladas pela presente Convenção e que não são expressamente resolvidas por ela serão decididas segundo os princípios gerais que a inspiram ou, na falta destes princípios, de acordo com a lei aplicável em virtude das regras de direito internacional privado.

Artigo 25 - Uma violação do contrato cometida por uma das partes é fundamental quando causa à outra parte um prejuízo tal que a prive substancialmente daquilo que lhe era legítimo esperar do contrato, salvo se a parte faltosa não previu esse resultado e se uma pessoa razoável, com idêntica qualificação e colocada na mesma situação, não o tivesse igualmente previsto.

Artigo 26 - Uma declaração de resolução do contrato apenas se torna eficaz quando notificada à outra parte.

Artigo 27 - Salvo disposição expressa em contrário da presente Parte da Convenção, se uma notificação, um pedido ou outra comunicação forem feitos por uma das partes do contrato, em conformidade com a presente Parte e por um meio adequado às circunstâncias, um atraso ou erro na transmissão da comunicação ou o fato de ela não ter chegado ao seu destino não priva aquela parte do direito de se prevalecer de tal comunicação.

Artigo 28 - Se, em conformidade com as disposições da presente Convenção, uma parte tiver o direito de exigir da outra a execução de uma obrigação, um tribunal não está vinculado a ordenar a execução específica, a não ser que a decretasse por aplicação do seu próprio direito relativamente a contratos de compra e venda semelhantes, não regulados pela presente Convenção.

Artigo 37 - Em caso de entrega antecipada, o vendedor tem direito, até a data prevista para a entrega, quer a entregar uma parte ou uma quantidade em falta ou mercadorias não-conformes ao contrato, quer a reparar qualquer falta de conformidade das mercadorias, novas em substituição das mercadorias, desde que o exercício deste direito não cause ao comprador inconvenientes ou despesas irrazoáveis. Contudo, o comprador conserva o direito de pedir uma indenização por perdas e danos, em conformidade com a presente Convenção.

Artigo 38 - 1. O comprador deve examinar as mercadorias ou fazê-las examinar num prazo tão breve possível, tendo em conta as circunstâncias. 2 . Se o contrato implicar um transporte das mercadorias, exame pode ser diferido até a chegada destas ao seu destino. 3. Se as mercadorias forem reenviadas em trânsito ou reexpedidas pelo comprador sem que este tenha tido razoavelmente a possibilidade de as examinar e se, no momento da conclusão do contrato, o vendedor conhecia ou deveria conhecer a possibilidade desse reenvio em trânsito ou dessa reexpedição. $O$ exame pode ser diferido até a chegada das mercadorias ao seu novo destino.

Artigo 39 - 1. O comprador perde o direito de se prevalecer de uma falta de conformidade das mercadorias se não a denunciar ao vendedor, precisando a natureza desta falta, num prazo razoável a partir do momento em que a constatou ou deveria te constatado. 2. Em qualquer caso, o comprador perde o direito de se prevalecer de uma falta de conformidade se não a denunciar ao vendedor até dois anos a partir da dat em que as mercadorias lhe foram efetivamente remetidas, a não ser que este prazo seja incompatível com a duração de uma garantia contratual.

Artigo 43 - 1 . O comprador perde o direito de se prevalecer das disposições dos artigos 41 e 42 se não denunciar ao vendedor o direito a pretensão do terceiro, precisando a natureza deste direito ou desta pretensão, num prazo razoável a partir do momento em que teve ou deveria ter tido conhecimento deles. 2. O vendedor não pode prevalecer-se das disposições do parágrafo anterior se conhecia o direito ou a pretensão do terceiro e a sua natureza.

Artigo 45 - 1 . Se o vendedor não executar qualquer das obrigações que para ele resultam do contrato de compra e venda ou da presente Convenção, o comprador está autorizado a: (a) exercer os direitos previstos nos artigos 46 a 52; (b) pedir a indenização por perdas e danos prevista nos artigos 74 a 77. 2. O comprador não fica privado do direito de pedir indenização por perdas e danos se exercer o seu direito de recorrer um outro meio. 3. Nenhum prazo suplementar pode ser concedido ao vendedor por um juiz ou por um árbitro quando o comprador se prevalecer de um dos meios de que dispõe em caso de violação do contrato.

Artigo 46 - 1. O comprador pode exigir do vendedor a execução das suas obrigações, a não ser que se tenha prevalecido de um meio incompatível com esta exigência. 2. Se as mercadorias não estiverem conformes ao contrato, o comprador apenas pode exigir do vendedor a entrega de mercadorias de substituição se a falta de conformidade constituir uma violação fundamental do contrato e se a substituição de mercadorias foi exigida no momento da denúncia da falta de conformidade, feita nos termos do artigo 39 , ou num prazo razoável a contar desta denúncia. 3. Se as mercadorias não são conformes ao contrato, o comprador pode exigir do vendedor que repare a falta de conformidade, salvo se isso for irrazoável, tendo em conta todas as circunstâncias. A reparação deve ser exigida no momento de denúncia da falta de conformidade, feita nos termos do artigo 39, ou num prazo razoável a contar desta denúncia.

Artigo 47 - 1. O comprador pode conceder ao vendedor um prazo suplementar, de duraça razoável, para a execução das suas obrigações. 2. Salvo se o comprador tiver 
recebido do vendedor uma notificação informando-o de que este não executaria as suas obrigações no prazo assim concedido, ele não pode, no decurso deste prazo, prevalecer-se de qualquer dos meios de que dispõe em caso de violação do contrato. Contudo, o comprador não perde, por este fato, qualquer direito que tenha de pedir uma indenização por perdas e danos pelo atraso na execução.

Artigo 48 - 1. Sem prejuízo do disposto no artigo 49, o vendedor pode, mesmo após a data da entrega, reparar à sua custa qualquer falta às suas obrigações, desde que isso não implique um atraso irrazoável e não cause ao comprador nem inconvenientes irrazoáveis nem incertezas quanto ao reembolso pelo vendedor das despesas feitas pelo comprador. Contudo, o comprador conserva o direito de pedir indenização por perdas e danos, nos termos da presente Convenção. 2. Se o vendedor exigir do comprador que lhe faça saber se aceita a execução, e se o comprador não the responder num prazo razoável, o vendedor pode executar as suas obrigações no prazo que indicou no seu pedido. $O$ comprador não pode, no decurso deste prazo, prevalecer-se de um meio incompatível com a execução pelo vendedor das suas obrigações. 3. Se o vendedor comunicar ao comprador a intenção de executar as suas obrigações num prazo determinado, presume-se que ele pede ao comprador que lhe faça conhecer a sua decisão nos termos do parágrafo anterior. 4. Um pedido ou uma notificação feitos pelo vendedor, nos termos dos parágrafos 2 ou 3 do presente artigo, não são eficazes se não forem recebidos pelo comprador.

Artigo 49 - 1. O comprador pode declarar o contrato resolvido: (a) se a inexecução pelo vendedor de qualquer uma das obrigaçōes que resultam para ele do contrato ou da presente Convenção constituir uma violação fundamental do contrato; ou (b) em caso de falta de entrega, se o vendedor não entregar as mercadorias no prazo suplementar concedido pelo comprador, de acordo com o parágrafo 1 do artigo 47 , ou se declarar que não as entregará no prazo assim concedido. 2. Todavia, se vendedor entregou as mercadorias, o comprador perde o direito de declarar o contrato resolvido, se não o fez: (a) em caso de entrega tardia, num prazo razoável a partir do momento em que soube que a entrega tinha sido efetuada; (b) em caso de outra violação contratual que não a entrega tardia, num prazo razoável: (I) a partir do momento em que teve ou deveria ter tido conhecimento da violação do contrato; (II) após o decurso de qualquer prazo suplementar concedido pelo comprador, de acordo com o parágrafo 1 do artigo 47, ou depois de o vendedor ter declarado que não executaria as suas obrigações neste prazo suplementar; ou (III) após o decurso de qualquer prazo suplementar indicado pelo vendedor, nos termos do parágrafo 1 do artigo 48, ou depois de o comprador ter declarado que não aceitaria a execução.

Artigo 61 - 1. Se o comprador não executar qualquer das obrigações que para ele resultam do contrato de compra e venda ou da presente Convenção, o vendedor está autorizado a: (a) exercer os direitos previstos nos artigos 62 a 65 ; (b) pedir a indenização por perdas e danos prevista nos artigos 74 a 77. 2. O vendedor não fica privado do direito de pedir indenização por perdas e danos se exercer o seu direito de recorrer a um outro meio. 3 . Nenhum prazo suplementar pode ser concedido ao comprador por um juiz ou por um árbitro quando o vendedor se prevalecer de um dos meios de que dispõe em caso de violação do contrato.

Artigo 63 - 1. O vendedor pode conceder ao comprador um prazo suplementar, de duração razoável, para a execução das suas obrigações. 2. Salvo se o vendedor tiver recebido do comprador uma notificação informando-o de que este não executaria as suas obrigações no prazo assim concedido, ele não pode, no decurso deste prazo, prevalecer-se de qualquer dos meios de que dispõe em caso de violação do contrato. Contudo, o vendedor não perde, por este fato, qualquer direito que tenha de pedir uma indenização por perdas e danos pelo atraso na execução.

Artigo 64 - 1. O vendedor pode declarar o contrato resolvido: (a) se a inexecução pelo comprador de qualquer uma das obrigações que resultam para ele do contrato ou da presente Convenção constituir uma violação fundamental do contrato; ou (b) se o comprador não executar a sua obrigação de pagar o preço ou não aceitar a entrega das mercadorias no prazo suplementar concedido pelo vendedor, de acordo com o parágrafo 1 do artigo 63 , ou se declarar que não o fará no prazo assim concedido. 2. Todavia, se o comprador pagou o preço, o vendedor perde o direito de declarar o contrato resolvido, se não o fez: (a) em caso de execução tardia pelo comprador, antes de ter sabido que a execução teve lugar; ou (b) em caso de outra violação contratual do comprador que não a execução tardia, num prazo razoável: (I) a partir do momento em que o vendedor teve ou deveria ter tido conhecimento da violação do contrato; ou (II) após o decurso de qualquer prazo suplementar concedido pelo vendedor, de acordo com o parágrafo 1 do artigo 63 , ou depois de o comprador ter declarado que não executaria as suas obrigações neste prazo suplementar.

Artigo $65-1$. Se, de acordo com o contrato, o comprador tiver de especificar a forma, a medida ou outras características das mercadorias e se não efetuar esta especificação na data acordada, ou um prazo razoável a partir da recepção de um pedido do vendedor, este pode, sem prejuízo de quaisquer outros direitos que possa ter, efetuar ele próprio esta especificação segundo as necessidades do comprador de que possa ter conhecimento. 2. Se o vendedor efetuar ele próprio a especificação, deve levar ao conhecimento do comprador as particularidades desta e fixar-lhe um prazo razoável para uma especificação diferente. Se, após a recepção da comunicação do vendedor, o comprador não utilizar esta possibilidade no prazo assim fixado, a especificação efetuada pelo vendedor torna-se vinculativa.

Artigo 73 - 1 . Nos contratos com prestações sucessivas, se a inexecução por uma das partes de qualquer das suas obrigações relativas a uma prestação constituir uma violação fundamental do contrato no que respeita a esta prestação, a outra parte pode declarar a resolução do contrato em relação a tal prestação. 2. Se a inexecução por uma das partes de qualquer das suas obrigações relativas a uma prestação der à outra parte sérias razões para concluir que uma violação fundamental do contrato terá lugar no que toca às prestações futuras, ela pode declarar a resolução do contrato para o futuro, desde que o faça num prazo razoável. 3 . O comprador que declarar a resolução do contrato relativamente a qualquer prestação pode, ao mesmo tempo, declará-lo resolvido relativamente às prestações já efetuadas ou às prestações futuras se, em virtude da sua interdependência, estas prestações não puderem ser utilizadas para o fim previsto pelas partes no momento da conclusão do contrato.

Artigo 74 - As perdas e danos decorrentes de uma violação do contrato cometida por uma das partes compreendem o prejuízo causado à outra parte, bem como os benefícios que esta deixou de receber em conseqüência da violação contratual. Tais perdas e danos não podem exceder o prejuízo sofrido e o lucro cessante que a parte faltosa previu ou deveria ter previsto no momento da conclusão do contrato com conseqüên cias possíveis de violação deste, tendo em conta os fatos de que ela tinha ou deveria ter tido conhecimento.

Artigo 75 - Se o contrato for resolvido e se, por forma e num prazo razoável após a resolução, o comprador procedeu a uma compra de substituição ou o vendedor a uma venda compensatória, a parte que pede indenização por perdas e danos pode obter a diferença entre o preço do contrato $e$ o preço da compra de substituição ou da venda compensatória, bem como qualquer outra indenização por perdas e danos que possa ser devida em virtude do artigo 74 .

Artigo $76-1$. Se o contrato for resolvido e as mercadorias tiverem um preço corrente, a parte que pede indenização por perdas e danos, se não procedeu a uma compra de substituição ou a uma venda compensatória nos termos do artigo 75 , pode obter a diferença entre o preço fixado no contrato e o preço corrente no momento da resolução, bem como qualquer outra indenização por 
perdas e danos que seja devida em virtude do artigo 74. No entanto, se a parte que pede indenização por perdas e danos resolveu o contrato depois de ter tomado posse das mercadorias, é o preço corrente no mo mento em que tomou posse delas que é o aplicável e não o preço corrente no momento da resolução. 2. Para os efeitos do pará grafo anterior, o preço corrente é o preço do lugar onde a entrega das mercadorias deveria ter sido efetuada ou, na falta de preço corrente nesse lugar, o preço corrente praticado noutro lugar que se afigure razoável tomar como ponto de referência, tendo em devida conta as diferenças no custo do transporte das mercadorias.

Artigo 77 - A parte que invoca a violação do contrato deve tomar as medidas razoá veis, face às circunstâncias, para limitar perda, aí compreendido o lucro cessante, resultante da violação contratual. Se não fizer, a parte faltosa pode pedir uma redução da indenização por perdas e danos no mo mento da perda que deveria ter sido evitada.

Artigo 79 - 1. Uma parte não é responsável pela inexecução de qualquer das suas obrigações se provar que tal inexecução se ficou a dever a um impedimento alheio sua vontade e que não era razoável espera que ela o tomasse em consideração no momento da conclusão do contrato, o prevenisse ou o ultrapassasse, ou que preveniss ou ultrapassasse as suas conseqüências. 2 . Se o não-cumprimento de uma parte se ficou a dever ao não-cumprimento de terceiro que ela encarregou de executar o contrato total ou parcialmente, aquela parte só fica exonerada da sua responsabilidade: (a) se estive exonerada em virtude do disposto no parágrafo anterior; e (b) se o terceiro estivess também ele exonerado, caso as disposições daquele parágrafo the fossem aplicadas. 3 . A exoneração prevista pelo presente artigo produz efeitos enquanto durar o impedimento. 4. A parte que não executar as suas obrigações deve comunicar à outra parte impedimento e os efeitos deste sobre a sua capacidade de cumprir o contrato. Se a outra parte não recebe a comunicação num prazo razoável contado a partir do momento em que a parte faltosa conheceu ou deveria ter conhecido o impedimento, esta fica responsável pelas perdas e danos decorrentes da falt de recepção da comunicação. 5. As disposições do presente artigo não impedem as partes de exercer qualquer dos seus direitos, salvo o de obter indenização por perdas e danos, nos termos da presente Convenção.

Artigo 81 - 1. A resolução do contrato liberta ambas as partes das obrigações dele decorrentes sem prejuízo de qualquer indenização por perdas e danos que possa ser devida. A resolução não afeta quaisquer estipulações do contrato relativas à solução dos diferendos ou aos direitos e obrigações das partes em caso de resolução. 2. A parte que executou total ou parcialmente o contrato pode reclamar da outra parte a restituição de tudo aquilo que forneceu ou pagou a título de cumprimento daquele. Se ambas as parte estiverem obrigadas a proceder a restituição, devem efetuá-las simultaneamente.

Artigo 82 - 1 . O comprador perde o direito de declarar o contrato resolvido, ou de exigir do vendedor a entrega de mercadorias de substituição, se lhe é impossível restituir as mercadorias num estado sensivelmente idêntico àquele em que as recebeu. 2 . O parágrafo anterior não se aplica: (a) se impossibilidade de restituir as mercadorias, ou de as restituir num estado sensivelmente idêntico àquele em que $o$ comprador as recebeu, não se ficar a dever a um ato ou omissão seus; (b) se as mercadorias pereceram ou se deterioraram, no todo ou em parte, em conseqüência do exame prescrito no artigo 38; ou (c) se o comprador, antes do momento em que constatou ou deveria ter constatado a falta de conformidade, vendeu todas ou parte das mercadorias, no quadro de uma operação comercial normal, ou consumiu ou transformou todas ou part delas de acordo com o uso normal.

Artigo 83 - O comprador que perdeu o direito de declarar o contrato resolvido ou de exigir do vendedor a entrega de mercadorias de substituição, nos termos do artigo 92, conserva o direito de se prevalecer de todos os outros meios que lhe advenham do contrato e da presente Convenção.
Artigo $84-1$. Se o vendedor estiver obrigado a restituir o preço, deve também pagar juros sobre aquela quantia a partir do dia do pagamento. 2. O comprador deve entregar ao vendedor o equivalente a todo $e$ qualquer benefício que retirou das mercadorias ou de uma parte destas: (a) quando deva restituí-las no todo ou em parte; ou (b) quando se encontre impossibilidade de restituir as mercadorias no todo ou em parte ou de as restituir, no todo ou em parte, num estado sensivelmente idêntico àquele em que as recebeu, e mesmo assim declarou o contrato resolvido ou exigiu do vendedor a entrega de mercadorias de substituição.

Artigo 88 - 1. A parte que estiver obrig da a assegurar a conservação das mercadorias, nos termos dos artigos 85 e 86 , pode vendê-las por todos os meios apropriados se a outra parte se atrasou de modo irrazoável a tomar posse das mercadorias, ou a retomá-las ou a pagar o preço ou as despesas de conservação, desde que notifique a outra parte, em condições razoáveis, da sua intenção de proceder à venda. 2 . Se as mercadorias estiverem sujeitas a uma rápida deterioração ou se a sua conservação provocasse despesas excessivas, a parte que estiver obrigada a assegurar a conservação das mercadorias nos termos dos artigos 85 e 86 , deve empenhar-se, de modo razoável, em vendêlas. $\mathrm{Na}$ medida do possível, deve notificar à outra parte a sua intenção de proceder à venda. 3. A parte que vender as mercadorias tem o direito de deduzir do produto $\mathrm{da}$ venda um montante igual às despesas razoáveis feitas com a conservação e a venda das mercadorias, devendo entregar o remanescente à outra parte.

\section{Anexo II}

Legislação brasileira citada

Código civil

Artigo 177 - As ações pessoais prescre vem, ordinariamente, em vinte anos, as reais, em dez, entre presentes e entre ausen- tes, em quinze, contados da data em que poderiam ter sido propostas.

Com a nova redação dada pela Lei $\mathrm{n}^{\circ}$ 2.437 , de 07/03/1955. O direito do IAPAS de receber ou cobrar importâncias devidas ao FPAS e ao FLPS prescreve em 30 (trinta) anos (Decreto $\mathrm{n}^{2}$ 83.081, de 24/01/1979, art. 154).

Artigo 178 - Prescreve: $\S 9, \mathrm{~V}$ - A ação de anular ou rescindir os contratos, para a qual se não tenha estabelecido menor prazo; contado este: (a) no caso de coação, do dia em que ela cessar; (b) no de erro, dolo, simulação ou fraude, do dia em que se realizar o ato ou o contrato; (c) quanto aos atos dos incapazes, do dia em que cessar a incapacidade.

Artigo 866 - Deteriorada a coisa, não sendo o devedor culpado, poderá o credor resolver a obrigação, ou aceitar a coisa, abatido ao seu preço o valor que perdeu. V. art. 871.

Artigo 955 - Considera-se em mora o devedor que não efetuar o pagamento, e o credor que o não quiser receber no tempo, lugar e forma conveniados (art. 1.058). V. art. 963. V. Código Comercial, arts. 137 e 138.

Artigo 956 - Responde o devedor pelos prejuízos a que a sua mora der causa (art. 1.058). V. arts. 1.056 e 1.062 . Acréscimo de juros no caso de mora de débito fiscal - V. art. 161 da Lei no 5.172, de 25/10/1966 (Cód. Tributário Nacional).

Artigo 963 - Não havendo fato ou omissão imputável ao devedor, não incorre este em mora. V. art. 909.

Artigo 1.056 - Não cumprindo a obrigação, ou deixando de cumpri-la pelo modo e no tempo devidos, responde o devedor por perdas e danos. V. arts. 865, 016, 955, $956,1.092$, parágrafo único, e 1.097. Responsabilidade contratual relativa aos transportes aéreos - V. arts. 97 a 108 do Decreto-lei no 32, de 18/11/1966 (Cód. do Ar). O inadimplemento de obrigação relativa a ajuste salarial foi erigido em crime e equiparado à sonegação fiscal, pelo art. 10 do Decreto-lei nº 15, de 19/07/1966. 
Artigo 1.092 - Nos contratos bilaterais, nenhum dos contraentes, antes de cumprida a sua obrigação, pode exigir o implemento da do outro. Se, depois de concluído o contrato, sobrevier a uma das partes contratantes diminuição em seu patrimônio, capaz de comprometer ou tornar duvidosa a prestação pela qual se obrigou, pode a parte, a quem incumbe fazer prestação em primeiro lugar, recusar-se a esta, até que a outra satisfaça a que lhe compete ou dê garantia bastante de satisfazê-la. V. arts. 954, $1.056,1.130$ e 1.131 . V. art. 198 do Código Comercial. No Estado de São Paulo, o Decreto $\mathrm{n}^{\circ} 46.118$, de $18 / 03 / 1966$, estabelece normas para reajustamento de preços nos contratos de natureza pública.

Artigo 1.163 - Ajustado que se desfaça a venda, não se pagando o preço até certo dia, poderá o vendedor, não pago, desfazer o contrato, ou pedir o preço. V. arts. 647,960 e 1.092, parágrafo único. Parágrafo único $\mathrm{Se}$, em dez dias de vencido o prazo, o vendedor, em tal caso, não reclamar o preço, ficará de pleno direito desfeita a venda.

\section{Código comercial}

Artigo 202 - Quando o vendedor deixa de entregar a coisa vendida no tempo aprazado, o comprador tem opção, ou de rescindir o contrato, ou de demandar o seu cumprimento com os danos da mora; salvo os casos fortuitos ou de força maior. Inexecução das obrigações: arts. 1.056 a 1.058 1.092, parágrafo único, do Código Civil.

Artigo 204 - Se o comprador sem justa causa recusar receber a coisa vendida, ou deixar de a receber no tempo ajustado, terá o vendedor ação para rescindir o contrato, ou demandar o comprador pelo preço com os juros da mora; devendo, no segundo caso, requerer depósito judicial dos objetos vendidos por conta e risco de quem pertencer. Consignações: arts. 973 e segs. e 1.092, parágrafo único, do Código Civil.

Artigo 212 - Se o comprador reenvia a coisa comprada ao vendedor, e este a aceita (art. 76), ou, sendo-lhe entregue contra sua vontade, a não faz depositar judicialmente por conta de quem pertencer, com intimação do depósito ao comprador, presume-se que consentiu na rescisão da venda.

\section{Notas}

Em se tratando de venda internacional, tem atualidade a questão de venda de gás pela Argentina ao Brasil, com a construção de projetado gasoduto. $\mathrm{O}$ art. $2^{2}$ da Convenção exclui do seu âmbito a venda de etricidade. No "Colóquio de Lausanne" (1984), Volen formulou a questão de abrangência de outras fortróleo energia, entendendo Widmer e Loewe que o fonte de energia "palpável", restando em aberto questão do gás (Volken, Champ d'application, interprátation, lacunes, usages. In: Convention de Vienne de 1980. Colloque de Lausanne des 19 et 20 novembre 1984. Instituts suisse de droit comparé, Zürich, Schulthess Polygraphischer Verlag, 1985, pp. 21-38). Aceito o princípio de que o não-excluído está incluído, deve ser admitida a incidência da Convençãa sobre a compra e venda internacional de gás.

Pontes de Miranda, Tratado de Direito Privado, v. I 60.

David, René. Les contrats en droit anglais. Paris, LGDJ, 1973, p. 371

$\mathrm{O}$ art. 32 da Lei $\mathrm{n}^{\circ} 6.766 / 79$, sobre o parcelarnento do solo urbano, prevê caso de resolução legal que se constitui por simples notificação ao devedor inadim. plente.

A resolução automática, independente de notícia à contraparte, foi considerada causadora de confusão e incerteza sobre os direitos e deveres dos contratantes. Da in Sam

P. Widmer. Droits et obligations du vendeur. In: Colloque de Lausanne, cit. p. 91-104/95; P. Tercier, Droits et obligations de L'Acbeteur. In: Colloque de Lausanne, cit. pp. 119-42/134.

7 Somente para estas prestaçōes poderá ser concedido prazo suplementar para o efeito de, uma vez desaten. dido, dar margem à resolução do contrato. $O$ descum. primento de obrigação de outra natureza não oportuniza a estipulação de prazo suplementar ao fim do qual poderia o credor declarar resolvido o contrato; o incumprimento destas outras obrigaçōes somente autoriza a resolução se constituírem violação fundamental, nos termos do art. 25. Já a desatenção ao prazo suplementar para cumprimento da obrigação principal caracteriza presumidamente violação fundamental.

Larenz, Derecbo de obligaciones, 1958, v. 1, p. 303

O princípio da boa-fé objetiva, apesar de não acolhi. do expressamente no nosso Código Civil, apenas refe- rido brevemente no velho Código Comercial de 1850 (art. 131: "Sendo necessário interpretar as cláusulas do contrato, a interpretação, além das regras sobreditas, será regulada sobre as seguintes bases: a inteligência simples e adequada, que for mais conforme a boa-fé, e ao verdadeiro espírito e natureza do contrato, deverá sempre prevalecer à rigorosa e restrita significação das palavras") tinha plena vigência no Direito brasileiro ainda antes da promulgação do Código de Defesa do Consumidor (Lei no 8.078, de 11.9.90) (cfr. Clóvis do Couto e Silva. O princípio da boaffé no Direito brasileiro e portugués. In: Estudos de Direito civil brasileiro português. São Paulo, Revista dos Tribunais, 1980, pp. 43-61). Hoje, o Código de Defesa do Consumidor tem regra expressa, aplicável a todo o sistema: é nula cláusula incompativel com a boa-fé (art. 51, IV)

10 Farnsworth, E. Allan. Rights and obligations of the seller. In: Colloque de Lausanne, pp. 83-90.

${ }^{11}$ Ao direito de o comprador exigir a reparação contrapóe-se o direito de o vendedor efetuar os reparos, art. 48 e do art. 37

12 Nào cabe a resolução se o vendedor reparou a falta, no caso de entrega antecipada (art. 37).

${ }^{13} \mathrm{Na}$ lição de Tercier, o descumprimento dos deveres acessórios do comprador, como os de examinar a me cadoria, dar aviso dos defeitos, assegurar a sua conservação, vender as mercadorias, quando for o caso (art. 88), não permite requerimento de execução, causando apenas a perda do direito do comprador ou ensejando a reparação do prejuizo sofrido (Droits et obligations de acbeteur. In: Colloque de Lausanne, pp. 119.42).

${ }^{14}$ Michael Will, Right to avoid contract. In: Commentary on the international sales law, pp. 359-67, art. 49.

${ }^{15}$ Além de não se aplicar esta disposição aos casos em que a própria Convenção se refere a uma declaração eceptícia, como no art. 48,4 , também não se estende aos atos necessários à formação do contrato.

16 Victor Knapp. Damages in general. In: Commentary on the international sales law, pp. 538-48.

7 Pontes de Miranda, Tratado de Direito Privado, v. 38 , p. 340. Ruy Rosado de Aguiar Jr., A Extinsão dos Con tratos por Incumprimento do

18 É discutivel a afirmaga de que o prazo de quatro anos a que se refere 0 art $178, \S$ qo anos a que se refere o ant. $178, \$$ prazo de rescindir os contres), que atinge direito formar para de promer a acão de anuacáo do contrato por vício de vontade aplica-se também para a acão por incum primento do devedor. Isto porque a acão de resolucão não é passível de prescrição nem decorre de vício de vontade existente ao tempo da celebração do contrato, a partir do qual o referido artigo manda seja contado o prazo prescricional.

${ }^{19}$ Cfr. Widmer. Droits et obligations du vendeur. Colloque de Lausanne, 91-107.

${ }^{20} \mathrm{Cfr}$. Bonell, 65-94, Interpretention of convention, p. 84 p. 69). 